Noman 2017, 35(1), 39-50

Revista de Psicologia, Ciències de l'Educació i de l'Esport

ISSN: 1138-3194

Copyright (C) 2017

www.revistaaloma.net

\title{
The Portrait Values Questionnaire: A bibliographic and bibliometric review of the instrument
}

\author{
Jordi Simón ${ }^{1}$, Carles Pérez-Testor ${ }^{1}$, Elizabeth Alomar ${ }^{1}$, Francesca Danioni², \\ Leire Iriarte ${ }^{3}$, Susana Cormenzana ${ }^{3}$, Ana Martínez ${ }^{3}$ \\ ${ }^{1}$ Ramon Llull University, ${ }^{2}$ Catholic University of Milan, ${ }^{3}$ University of Deusto
}

Received: 27-3-2017

Accepted: 19-4-2017

The Portrait Values Questionnaire: A bibliographic and bibliometric review of the instrument

\begin{abstract}
Summary. This paper contains a bibliographic and a bibliometric review of the Portrait Values Questionnaire $(P V Q)$, the instrument proposed by Schwartz to assess human values. Schwartz's theory of human values is one of the most popular of its kind in the social sciences. To set out the framework of the PVQ we shall briefly present the underlying theory, followed by a discussion of the different instruments developed by Schwartz to assess human values. Finally, we have performed a detailed review to analyse how the PVQ has been used in the scholarly literature. A total of 58 articles were reviewed to obtain a picture of how the scientific community uses this instrument and to explore the variables most commonly related to human values. Several conclusions are briefly discussed.
\end{abstract}

Keywords: values; Portrait Values Questionnaire; bibliographic review

El Portrait Values Questionnaire: una revisió bibliogràfica i bibliomètrica de l'instrument

Resum. El Portrait Values Questionari (PVQ), és l'instrument proposat per Schwartz per avaluar els valors personals. La teoria dels valors personals de Schwartz és una dels més difoses en estudis sobre valors en les ciències socials. En aquest article es presenta una revisió bibliogràfica i bibliomètrica del Portrait Values Questionnaire (PVQ). En primer lloc presentem breument la teoria i els diferents instruments desenvolupats per Schwartz per avaluar els valors personals. Seguidament s'exposa la revisió descriptiva d'un total de 58 articles que ens ha permès analitzar com el PVQ s'ha utilitzat en la literatura acadèmica. Els resultats de la recerca ens permeten obtenir una imatge de com la comunitat científica utilitza aquest instrument i per explorar les variables més comunament relacionats amb els valors personals. Al final de l'article es discuteixen i presenten diferents conclusions com per exemple la transversalitat de l'ús d'aquest instrument.

Paraules clau: valors; Portrait Values Questionnaire; revisió bibliogràfica

Correspondence:

Jordi Simón i Llovet

Faculty of Psychology, Education, and Sport Science

Blanquerna.

Ramon Llull University

c/ Císter 3408022 Barcelona, Spain.

Email: jordisl@blanquerna.url.edu 


\section{Introduction}

The concept of values has been studied by many different disciplines, including psychology, sociology, philosophy and even economics, and these fields have proposed a range of definitions of this term. Inquiry into human values is therefore not limited solely to the field of psychosocial research. In fact, all these disciplines believe that knowledge of human values allows us to better understand other important variables, such as human behaviours, decisions and attitudes.

This article is divided into three different parts. In Part I, we present a brief overview of Schwartz's theory of human values. In Part II, we explain the two most important instruments used to assess human values: the Schwartz Value Survey and the Portrait Values Questionnaire. In Part III we examine how the Portrait Values Questionnaire (Schwartz, Melech, Lehmann, Burgess, \& Harris, 2001) has been used in the scholarly literature. Our goal is to highlight the studies that have analysed the role of human values in different life situations and their relationships with various outcomes. More specifically, our purpose is to analyse studies with a variety of research aims that have used the Portrait Values Questionnaire to assess human values . Finally, we briefly discuss several general conclusions about how the instrument has been used.

\section{PART I}

The concept of value: Schwartz's Theory of Basic Values

Shalom Schwartz founded his theory of values on Milton Rokeach's conceptual framework (1973). The latter author defined a value as 'an enduring belief that a specific mode of conduct or end state of existence is personally or socially preferable to an opposite or converse mode of conduct or end state of existence' (p. 5) and explained that every human being's values continually change over time, as opposed to enduring as stable personality traits. Values derive from three needs of human existence: needs of individuals as biological organisms, coordinated social interaction, and group efficacy and survival. Basing his theory on this main idea, Schwartz (1992; 1994) defined values as desirable, abstract, transsituational goals with varying degrees of importance that serve as guiding principles in people's lives. The author therefore developed one of the most recognised theories of this notion in the social sciences. There is agreement in the literature that all human values share five common features: 'Values: a) are concepts or beliefs, b) pertain to desirable end states or behaviours, c) transcend specific situations, d) guide selection or evaluation of behaviours and events, and e) are ordered in relative importance' (Schwartz \& Bilsky, 1990, p. 878). Therefore, every value is distinct from others because of the motivational goal that underlies it. Schwartz identified the existence of ten basic values which encapsulate all possible values (see Table 1 ).
Table 1. Motivational Values Type (Schwartz, 1992)

\begin{tabular}{ll}
\hline Value types & Motivational Goal \\
\hline Universalism & $\begin{array}{l}\text { Understanding, appreciation, tolerance and protection } \\
\text { for the welfare of all people and nature }\end{array}$ \\
\hline Benevolence & $\begin{array}{l}\text { Preservation and enhancement of the welfare of people } \\
\text { with whom one is in frequent and personal contact }\end{array}$ \\
\hline Tradition & $\begin{array}{l}\text { Respect, commitment and acceptance the customs and } \\
\text { ideas that traditional culture or religion provide }\end{array}$ \\
\hline Conformity & $\begin{array}{l}\text { Restraints of actions, inclinations and impulses likely } \\
\text { to upset or harms others and violate social expectations } \\
\text { or norms }\end{array}$ \\
\hline Security & $\begin{array}{l}\text { Safety, harmony and stability of society, of relationships } \\
\text { and of self }\end{array}$ \\
\hline Power & $\begin{array}{l}\text { Social status and prestige, control or dominance over } \\
\text { people and resources }\end{array}$ \\
\hline Achievement & $\begin{array}{l}\text { Personal success through demonstrating competence } \\
\text { according to social standards }\end{array}$ \\
\hline Hedonism & \begin{tabular}{l} 
Pleasure and sense of gratification for oneself \\
\hline Stimulation
\end{tabular} \\
\hline Excitement, novelty, and challenge in life \\
\hline
\end{tabular}

Schwartz then organised these ten values in a circular structure based on the possibility that two values can be compatible or incompatible: this arrangement of values also represents a motivational continuum. Values characterised by similar motivational goals appear next to each other in the circle, while those whose motivational goals are different are in opposite positions. For example, the pursuit of Benevolence values (e.g., helping others and caring for their wellbeing) is compatible with the pursuit of Universalism values (e.g., tolerating and protecting other people and nature), but it conflicts with the pursuit of Power values (e.g., dominating other people, being rich).

It is also possible to fit the ten basic human values into four higher-order value types that create two orthogonal bipolar dimensions. On the one hand, we can observe the opposition between Self-transcendence (Universalism and Benevolence values) and Self-enhancement (Power and Achievement values). On the other hand, the second bipolar dimension contrasts the poles Openness to change (Hedonism, Stimulation and Self-direction) and Conservation (Tradition, Conformity and Security) (Schwartz, 1992). In 2012, Schwartz and his colleagues, proposed a refined version of this theory, with the aim of providing greater heuristic and explanatory power than the original theory. Specifically, in this recent work they offered narrower definitions founded upon their empirical findings of a few of the ten basic values, resulting in an expanded list of 19 values and in a finer distinction of the previously theorised values.

Another relevant feature of values is their universality. Schwartz's model has, in fact, been confirmed by more than 200 studies in 60 countries that used samples from different geographic regions, languages, religions, ages, sexes and occupations (Schwartz et al., 2001). In light of the results of these cross-cultural studies, Schwartz has changed a few aspects of his theory, mainly by fine-tuning some of the material regarding the content of the values, but he has in the end con- 
firmed that the ten basic human values are universal guiding principles in everyday life (Schwartz, 1992; Schwartz et al., 2001).

\section{PART II \\ Instruments to assess values}

Psychosocial researchers have long expressed a great deal of interest in seeking ways to assess human values. Schwartz and his colleagues have developed several instruments to achieve this ambitious goal. The most important are the Schwartz Value Survey (SVS) (Schwartz, 1992) and the Portrait Values Questionnaire (Schwartz et al., 2001), both of which Schwartz developed himself.

\section{Schwartz Value Survey}

At first, Schwartz maintained Rokeach's distinction between Terminal and Instrumental Values. The former are desirable end-states of existence, the goals that a person wishes to achieve in his/her lifetime, whereas the latter are preferable ways of behaving or means of achieving terminal values (Rokeach, 1973). This distinction is evident in the first instrument Schwartz developed to assess the ten basic human values he theorised, namely the Schwartz Value Survey (SVS) (Schwartz \& Bilsky 1987; Schwartz \& Bilsky 1990; Schwartz 1994). The SVS presents two different lists (one for Instrumental values and another for Terminal values) of 57 single value-items (e.g., 'sense of belonging'), immediately followed by a brief explanation in parentheses of their meaning (e.g., 'feeling that others care about me'). Respondents are asked to indicate what extent they consider each of the values a guiding principle of their lives, rating them on a 9-point scale of importance, from 7 ('of supreme importance') to -1 ('opposed to my values'). However, since this task requires respondents to evaluate an abstract concept, Schwartz and his colleagues (2001) found that this instrument is not suitable for adolescents and persons not educated in Western schools. Because of this, and because this task is highly demanding, another instrument was developed: the Portrait Values Questionnaire (PVQ).

\section{Portrait Values Questionnaire}

The Portrait Values Questionnaire was proposed by Schwartz and his colleagues (2001) and has been validated in diverse contexts. The PVQ allows for the assessment of the same ten basic human values, but it is an easier and more concrete instrument than the SVS. This makes PVQ suitable for people who are unable to answer the SVS. The PVQ measures a person's values implicitly, meaning without revealing the topic being researched. In this way, it also lowers the effects of social desirability. Respondents are presented with forty portraits of people (or twenty-one, in a shortened version) each of which describes what is important to the hypothetical individual described. Both a male and a female version exist according to the respondent's gender (e.g., 'Thinking up new ideas and being creative is important to him/her. He/She likes to do things in his/her own original way' to measure a person's Self-direction value). The portraits were developed according to the theoretical definition of the concept of value (Schwartz, 1992; 1994) or by reformulating an item from the previous instrument. Values are inferred from how much the respondents consider themselves similar to the portrait described, and the average answers to the items that assess the same value are calculated. The respondent is asked to compare him/herself to each portrait, saying how much each description is similar to him/her on a 6-point scale, from 1 ('not like me at all') to 6 ('very much like me'). Two different versions of the instrument exist: the PVQ-40, comprised of 40 items, and a shortened one, the PVQ-21. In the original version, the number of items assessing the same value can vary: three each for Stimulation, Hedonism and Power; four each for Tradition, Benevolence, Universalism, Self-direction and Achievement; five for Security; and six for Universalism.

The factor structure of the PVQ and its cross-cultural validity (e.g., Burr, Santo, Pushkar, 2014; Solano \& Nader, 2006; Steinmetz, Schmidt, Tina-Booh, Wieczorek, \& Schwartz, 2009) have been widely investigated. The PVQ-40 displays good properties both in terms of the structure of the ten basic values (e.g., Steinmetz et al., 2009) and when it comes to the fourfactor model (e.g., Vecchione, Lönnqvist, Lipsanen \& Helkama, 2009). Meanwhile, the PVQ-21 is definitely a more valid instrument to assess the four-factor model (Verkasalo, Lönnqvist, Lipsanen, \& Helkama, 2009), and it showed an invariant structure across cultures (e.g., Davidov, Schmidt, \& Schwartz, 2008). Moreover, it test-retest reliability it has been found to be moderate to high (e.g., Schwartz, 2003).

Since the comparison between oneself and the portrait works automatically, it is quite easy to complete the PVQ, and it only takes respondents from 7 to 10 minutes (in the 40-item version) (Schwartz et al., 2001). This instrument can be used with children aged ten and older with adult assistance (Döring, 2010).

\section{PART III} Our study

The Portrait Values Questionnaire has been used in the scholarly literature by various authors for different purposes; the review presented here reports on the use of this most recent, common instrument to assess human values developed by Schwartz himself. The aim of this study is to describe how the Portrait Values Questionnaire has been used in the social sciences. More specifically, and in light of these considerations, this study has three aims:

1. To perform a bibliometric review to survey the authors who have focused their attention on this topic, where and when they have done so, the scope of these kinds of studies within the scholarly com- 
munity and the scientific journals which feature articles dealing with this topic.

2. To perform a methodological analysis of the PVQ, primarily focusing how it has been used in the studies included in the review.

3. To explore the different ways the PVQ has been used in the scholarly literature.

According to Montero and Leon (2007), this review falls within the category of classical theoretical studies in that it reviews ideas on a topic without using statistics.

\section{Method}

We conducted a literature search on May $2^{\text {nd }} 2016$ using the PsycINFO abstract database available at the Ramon Llull University, Barcelona, Spain. This database is maintained by the American Psychological Association (APA) and 'provides systematic coverage of the psychological literature from the 1800 s to the present. (...) PsycINFO contains bibliographic citations, abstracts, cited references, and descriptive information to help you find what you need across a wide variety of scholarly publications in the behavioral and social sciences'. We preferred to use this database for several reasons: first, because it is used extensively in the psychological sciences, which makes it the most common and best-known database of its kind in this field among the scholarly community. Secondly, with its advanced search options, it usually provides pertinent results. And thirdly, it allows users to search for different kinds of works, such as journal articles, books and dissertations. Moreover, each publication available in this database has been carefully selected for its relevance by a team of experts (APA, 2015).

The following keywords were used in the search: in Any Field, 'Portrait Values Questionnaire', in Age group: 'Young adulthood (18-29 years)' and in Year: '20072014'. We did not include the year 2015 because PsycINFO takes several months to update to include the publications from each year. The English language was chosen since the major records fields (Title, Summary, Keywords) are always collected in English. The full name of the instrument to measure values developed by Schwartz and his colleagues (2001) was entered as a keyword to ensure that every study using it was displayed, regardless of which version had been used. The age range was decided in light of the particular importance of the topic of values in this particular phase of the family life cycle, namely young adulthood (Grassi, 2007). Special attention was paid to the most important values of this population segment today (given that the topic of the shift in values from those of previous generations is incredibly interesting), and to what other variables these values influence, such as behaviours, decisions, etc. According to Arnett (2004), the term 'emerging adulthood' underscores the fact that this transition is long enough to be considered a separate period within the life course. The author proposes five features that distinguish this phase in the life cycle: it is the age of identity explorations, the age of instability, the self-focused age, the age of feeling in-between, and the age of possibilities.

The search yielded a total of 67 articles. Based on this result, we included in the review only the ones written in English, Italian or Spanish, thus excluding one in Portuguese (Tamayo \& Porto, 2009), one in Arabic (Delkhamous \& Ahmadi, 2013) and one in Turkish (Özcan, 2012). This inclusion criterion was adopted to reflect the authors' language skills. Moreover, articles that dealt with Schwartz's theory but did not make use of the PVQ (Liu, Gijsen, \& Tsai, 2013; Venus, Stam, \& van Knippenberg, 2013), and articles about studies using the SVS instead of the PVQ (Busacca, Beebe, \& Toman, 2010; Zhang, Ly, \& Grigoriou, 2008) were all excluded. We also left out two other articles because they were unavailable (Hofmann, 2010; Kulik \& Erantal, 2009). We did not exclude any of the articles that came from the search performed using PsycINFO because of the year of publication. All of them, in fact, were published between 2007 and 2014, and they were thus suitable for our review according to the exclusion and inclusion criteria. Ultimately, the remaining 58 articles were considered suitable for our review (Table 2).

These steps are documented in the PRISMA flow diagram (Moher, Liberati, Tetzlaff, Altman, \& The PRISMA Group, 2009) (Figure 1).

\section{Results}

The results are structured beginning with the bibliometric review, which is followed by the methodological analysis of the PVQ and then the exploration of the different ways the PVQ has been used in the scholarly literature.

We first considered the authors of the 58 studies included in the review. Schwartz himself, the author who developed both the theory of human values and the instrument that is the focus of this review, the PVQ, participated directly in four of the studies, in each case in conjunction with other colleagues. The authors who wrote more than one of the articles considered in our review are presented in Table 3.

Secondly, we identified the journals which most often tend to publish studies dealing with human values. Nine journals published more than one such article (Table 4), with a total of 20 of the 58 articles appearing in these periodicals. The remaining 38 articles were published in a range of journals, such as the Journal of Family Psychology and the British Journal of Psychology (see Table 4).

Table 5 shows how many of the 58 articles considered were published in each year from 2007 to 2014 .

It is worth remarking that $96,5 \%$ of the studies ( $N=56)$ were written in English, although this was always not the native language of the author(s) (e.g., Barni, Ranieri, Scabini, \& Rosnati, 2011). One of them was in Italian (Gerbino, Alessandri, \& Caprara, 2008), and one was in Spanish (Saiz, Álvaro, \& Martínez, 2010). 
Table 2. Studies dealing with the Portrait Values Questionnaire

\begin{tabular}{|c|c|c|c|c|c|c|}
\hline Source & Journal/Book & $\begin{array}{l}\text { Cross-cultural } \\
\text { (yes/no) }\end{array}$ & Likert scale & $\begin{array}{l}\text { Number } \\
\text { of items }\end{array}$ & $\begin{array}{l}\text { Values } \\
\text { assessed }\end{array}$ & Sample \\
\hline Arieli, Grant, \& Sagiv, 2014 & Journal of Personality & No & From 1 to 7 & Not said & 1 & 36 \\
\hline $\begin{array}{l}\text { Avallone, Farnese, Pepe, \& } \\
\text { Vecchione, } 2010\end{array}$ & Bollettino di Psicologia Applicata & No & Not said & Not said & All & 1,834 \\
\hline $\begin{array}{l}\text { Barni, Ranieri, Scabini, \& Rosnati, } \\
2011\end{array}$ & Journal of Moral Education & No & From 1 to 6 & 40 & All & 381 family triads \\
\hline $\begin{array}{l}\text { Barni, Alfieri, Marta, \& Rosnati, } \\
2013\end{array}$ & Journal of Adolescence & No & From 1 to 6 & 40 & All & 423 family triads \\
\hline $\begin{array}{l}\text { Barni, Roccato, Vieno, \& Alfieri, } \\
2014\end{array}$ & $\begin{array}{l}\text { Personality and Individual } \\
\text { Differences }\end{array}$ & No & From 1 to 6 & 21 & 3 & $\begin{array}{l}96 \text { families } \\
\text { (384 participants) }\end{array}$ \\
\hline $\begin{array}{l}\text { Barni, Vieno, Rosnati, } \\
\text { Roccato, \& Scabini, } 2014\end{array}$ & $\begin{array}{l}\text { European Journal of } \\
\text { Developmental Psychology }\end{array}$ & No & From 1 to 6 & 21 & 3 & $\begin{array}{l}677 \text { students and } \\
122 \text { teachers }\end{array}$ \\
\hline Bender \& Chasiotis, 2011 & $\begin{array}{l}\text { Journal of Cross-Cultural } \\
\text { Psychology }\end{array}$ & Yes & Not said & Reduced & 3 & 247 \\
\hline $\begin{array}{l}\text { Benish-Weisman, Levy, \& Knafo } \\
2013\end{array}$ & $\begin{array}{l}\text { Journal of Research on } \\
\text { Adolescence }\end{array}$ & No & From 1 to 6 & 40 & All & 564 adolescents \\
\hline Berzonsky \& Papini, 2014 & Identity & No & Not said & 21 & All & 235 \\
\hline Boratav, 2009 & $\begin{array}{l}\text { Perspectives on human } \\
\text { development, family, and culture }\end{array}$ & No & Not said & 40 & All & 1,000 \\
\hline Burr, Santo, \& Pushkar, 2014 & Quality \& Quantity & No & From 1 to $6^{*}$ & 40 & All & $\begin{array}{l}433 \text { retired adults } \\
\text { and } 199 \text { students }\end{array}$ \\
\hline Caprara \& Steca, 2007 & $\begin{array}{l}\text { Journal of Social and Clinical } \\
\text { Psychology }\end{array}$ & No & From 1 to $6^{*}$ & 40 & 2 & 1,324 \\
\hline $\begin{array}{l}\text { Caprara, Francescato, Mebane, } \\
\text { Sorace, \& Vecchione, } 2010\end{array}$ & Political Psychology & No & From 1 to $6^{*}$ & 21 & 4 & 971 \\
\hline $\begin{array}{l}\text { Caprara, Alessandri, \& Eisenberg, } \\
2012\end{array}$ & $\begin{array}{l}\text { Journal of Personality and Social } \\
\text { Psychology }\end{array}$ & No & From 1 to 6 & 40 & All & 340 \\
\hline Cieciuch \& Schwartz, 2012 & Journal of Personality Assessment & No & From 1 to 6 & 40 & All & 10,439 \\
\hline Cohen \& Liu, 2011 & $\begin{array}{l}\text { International Journal of } \\
\text { Psychology }\end{array}$ & No & From 1 to 6 & 40 & All & 192 teachers \\
\hline $\begin{array}{l}\text { Cohrs, Maes, Moschner, \& } \\
\text { Kielmann, } 2007\end{array}$ & Political Psychology & No & From 0 to 5 & 40 & 6 & 470 \\
\hline $\begin{array}{l}\text { de Barcellos, Teixeira, \& Venturini, } \\
2014\end{array}$ & $\begin{array}{l}\text { International Journal of Consumer } \\
\text { Studies }\end{array}$ & No & From 1 to 6 & 21 & All & 458 \\
\hline $\begin{array}{l}\text { Dirilen-Gumus \& Buyuksahin- } \\
\text { Sunal, } 2012\end{array}$ & Sex Roles & No & From 1 to $6^{*}$ & 40 & All & 231 students \\
\hline $\begin{array}{l}\text { Duriez, Soenens, \& Vansteenkiste, } \\
2007\end{array}$ & European Journal of Personality & No & & 8 & 4 & 724 \\
\hline $\begin{array}{l}\text { Duriez, Luyckx, Soenens, \& } \\
\text { Berzonsky, } 2012\end{array}$ & Journal of Personality & No & 5-point scale & 8 & 4 & 806 \\
\hline $\begin{array}{l}\text { Gerbino, Alessandri, \& Caprara, } \\
2008\end{array}$ & Età Evolutiva & No & From 1 to 6 & 40 & 4 & 548 \\
\hline $\begin{array}{l}\text { Goodwin, Polek, \& Goodwin, } \\
2013\end{array}$ & $\begin{array}{l}\text { Journal of Mixed Methods } \\
\text { Research }\end{array}$ & No & & Not said & 2 & 172 \\
\hline Güngör \& Bornstein, 2009 & Sex Roles & No & From 1 to $5^{\star}$ & 21 & All & 199 adolescents \\
\hline Güngör, Bornstein, \& Phalet, 2012 & $\begin{array}{l}\text { International Journal of } \\
\text { Behavioral Development }\end{array}$ & Yes & From 1 to $5^{\star}$ & 21 & All & 766 \\
\hline Hofmann-Towfigh, 2007 & Journal of Moral Education & No & & 40 & All & 719 students \\
\hline $\begin{array}{l}\text { Holtschlag, Morales, Masuda \& } \\
\text { Maydeau-Olivares, } 2013\end{array}$ & Journal of Vocational Behaviour & Yes & From 1 to $6^{*}$ & 21 & 2 & 35,463 \\
\hline $\begin{array}{l}\text { Kanacri, Pastorelli, Zuffianò, } \\
\text { Eisenberg, Ceravolo, \& Caprara, } \\
2014\end{array}$ & Journal of Adolescence & No & From 1 to 6 & 40 & 2 & 686 \\
\hline $\begin{array}{l}\text { Kjærgaard, Leon, Venables, \& } \\
\text { Fink, } 2013\end{array}$ & Military Psychology & No & & 40 & All & 12 \\
\hline Kretschmer \& Pike, 2010 & Journal of Family Psychology & No & From 1 to 6 & 17 & All & 205 siblings pairs \\
\hline $\begin{array}{l}\text { Livi, Leone, Falgares, \& Lombardo, } \\
2014\end{array}$ & $\begin{array}{l}\text { Personality and Individual } \\
\text { Differences }\end{array}$ & No & From 1 to 6 & 40 & All & 146 \\
\hline $\begin{array}{l}\text { Luengo Kanacri, Rosa, \& Di } \\
\text { Giunta, } 2012\end{array}$ & $\begin{array}{l}\text { Journal of Prevention \& } \\
\text { Intervention in the Community }\end{array}$ & No & From 1 to 6 & 40 & 3 & 564 \\
\hline Maercker et al., 2009 & $\begin{array}{l}\text { Psychology and Psychotherapy: } \\
\text { Theory, Research and Practice }\end{array}$ & Yes & From 1 to $6^{*}$ & 40 & 6 & 281 \\
\hline Nir \& Knafo, 2009 & $\begin{array}{l}\text { Values, empathy, and fairness } \\
\text { across social barriers }\end{array}$ & No & From 1 to $6^{*}$ & 40 & All & 98 \\
\hline Olsen et al., 2011 & Food and Quality Preferences & Yes & From 1 to 7 & 6 & All & 609 consumers \\
\hline $\begin{array}{l}\text { Ottaviani, Mancini, Petrocchi, } \\
\text { Medea, Couyoumdjian, } 2013\end{array}$ & $\begin{array}{l}\text { International Journal of } \\
\text { Psychophysiology }\end{array}$ & No & Not said & Not said & 2 & 40 \\
\hline
\end{tabular}


Table 2. Studies dealing with the Portrait Values Questionnaire (continuation)

\begin{tabular}{|c|c|c|c|c|c|c|}
\hline Source & Journal/Book & $\begin{array}{l}\text { Cross-cultural } \\
\text { (yes/no) }\end{array}$ & Likert scale & $\begin{array}{l}\text { Number } \\
\text { of items }\end{array}$ & $\begin{array}{l}\text { Values } \\
\text { assessed }\end{array}$ & Sample \\
\hline $\begin{array}{l}\text { Paciello, Fida, Tramontano, Cole, } \\
\text { \& Cerniglia, } 2013\end{array}$ & $\begin{array}{l}\text { European Journal of } \\
\text { Developmental Psychology }\end{array}$ & No & From 1 to $6^{*}$ & 40 (reduced) & 4 & 171 students \\
\hline Pallini, Bove, \& Laghi, 2011 & $\begin{array}{l}\text { Measurement and Evaluation in } \\
\text { Counselling and } \\
\text { Development }\end{array}$ & No & From 1 to 6 & 40 & All & 339 students \\
\hline Riekki, Lindeman, \& Lispanen, 2013 & Advances in Cognitive Psychology & No & & Not said & & 850 \\
\hline Robinson, 2013 & European Journal of Ageing & Yes & From 1 to $6^{*}$ & 21 & All & 44,955 \\
\hline Saiz, Álvaro, \& Martínez, 2011 & Addiciones & No & From 1 to 6 & 40 & All & 233 drug addicted \\
\hline $\begin{array}{l}\text { Sapienza, Hichy, Guarnera, \& Di } \\
\text { Nuovo, } 2010\end{array}$ & $\begin{array}{l}\text { International Journal of } \\
\text { Psychology }\end{array}$ & No & From 1 to 6 & 40 & All & 264 students \\
\hline $\begin{array}{l}\text { Schermer, Feather, Zhu, \& Martin, } \\
2008\end{array}$ & $\begin{array}{l}\text { Twin Research and Human } \\
\text { Genetics }\end{array}$ & No & From 1 to 6 & 40 & All & 690 twins \\
\hline $\begin{array}{l}\text { Schiefer, Mollering, Benish } \\
\text { Weisman, Boehnke, \& Daniel, } \\
2010\end{array}$ & $\begin{array}{l}\text { European Journal of Social } \\
\text { Psychology }\end{array}$ & Yes & From 1 to 6 & 25 & All & 3,223 students \\
\hline $\begin{array}{l}\text { Sandy, Gosling, \& Koelkebeck, } \\
2014\end{array}$ & Journal of Individual Differences & Yes & From 1 to 6 & 40 & All & 38,049 \\
\hline Schiefer, 2013 & $\begin{array}{l}\text { Journal of Cross-Cultural } \\
\text { Psychology }\end{array}$ & Yes & From 1 to $6+$ & 21 & All & N/A \\
\hline Schouten, 2008 & $\begin{array}{l}\text { International Journal of } \\
\text { Intercultural Relations }\end{array}$ & No & From 1 to 7 & 31 & 8 & 325 students \\
\hline Schwartz, \& Butenko, 2014 & $\begin{array}{l}\text { European Journal of Social } \\
\text { Psychology }\end{array}$ & No & From 1 to 6 & $\begin{array}{l}\text { PVQ-R, } \\
57 \text { items }\end{array}$ & $\begin{array}{l}\text { All (19 } \\
\text { values) }\end{array}$ & 266 \\
\hline Sevgili \& Cesur, 2014 & $\begin{array}{l}\text { Educational Sciences: Theory \& } \\
\text { Practice }\end{array}$ & No & From 1 to 6 & 40 & All & 485 \\
\hline Śliwak \& Zarzycka, 2013 & Psychologica Belgica & No & From 1 to 6 & 40 & All & 288 \\
\hline $\begin{array}{l}\text { Sørensen, Scholderer, Dutra de } \\
\text { Barcellos, Veflen Olsen, \& Verbek, } \\
2012\end{array}$ & Appetite & Yes & From 1 to 6 & 21 & All & 1,931 \\
\hline $\begin{array}{l}\text { Steinmetz, Schmidt, Tina-Booh, } \\
\text { Wieczorek, \& Schwartz, } 2009\end{array}$ & $\begin{array}{l}\text { International Journal of } \\
\text { Methodology }\end{array}$ & No & From 1 to 4 & 28 & All & 1,677 \\
\hline $\begin{array}{l}\text { Tulviste, Konstabel, \& Tulviste, } \\
2014\end{array}$ & $\begin{array}{l}\text { International Journal of } \\
\text { Intercultural Relations }\end{array}$ & Yes & From 1 to 6 & 21 & All & $\begin{array}{l}\text { Data from a round } \\
\text { of the ESS }\end{array}$ \\
\hline van der Noll, 2014 & $\begin{array}{l}\text { International Journal of } \\
\text { Intercultural Relations }\end{array}$ & No & Not said & 40 & All & 1,122 \\
\hline $\begin{array}{l}\text { Vecchione, Caprara, Schoen, } \\
\text { Gonzàlez, Casto, \& Schwartz, } 2012\end{array}$ & British Journal of Psychology & Yes & From 1 to 6 & 40 & 2 & 1,569 \\
\hline Vollmer \& Randler, 2012 & $\begin{array}{l}\text { Personality and Individual } \\
\text { Differences }\end{array}$ & No & From 0 to 5 & 21 & All & 1,344 \\
\hline Výrost, Fedáková, \& Kentoš, 2010 & Studia Psychologica & Yes & & 2 & 1 & 41,027 \\
\hline Woehr, Arciniega, \& Poling, 2013 & Woehr, Arciniega, \& Poling, 2013 & No & From 1 to 6 & 40 & 9 & 360 students \\
\hline
\end{tabular}

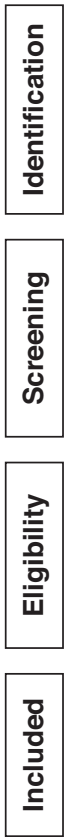

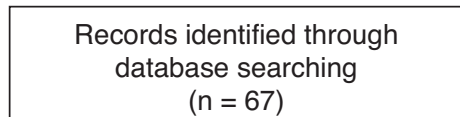

$(n=67)$ through other sources $(n=0)$

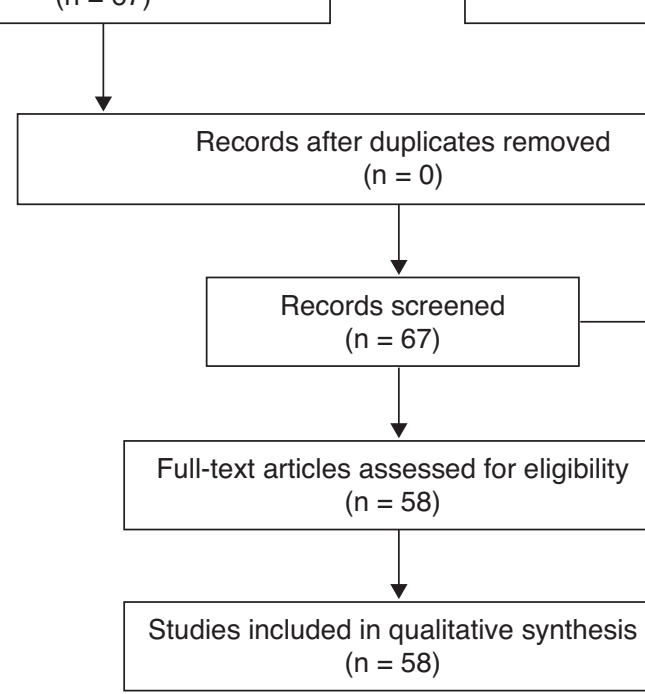

Records excluded

$(\mathrm{n}=5)$

Figure 1. The PRISMA flow diagram (Moher, Liberati, Tetzlaff, Altman, \& The PRISMA Group 2009). 
Table 3. Authors who published more than one article considered in the review

\begin{tabular}{ll}
\hline Author & Number of articles \\
\hline Gian Vittorio Caprara & 6 \\
\hline Daniela Barni & 4 \\
\hline Shalom H. Schwartz & 4 \\
\hline Rosa Rosnati & 3 \\
\hline Michele Vecchione & 3 \\
\hline Guido Alessandri & 2 \\
\hline Michael Berzonsky & 2 \\
\hline Marc H. Bornstein & 2 \\
\hline Maya Benish-Weisman & 2 \\
\hline Bart Duriez & 2 \\
\hline Derya Güngör & 2 \\
\hline Ariel Knafo & 2 \\
\hline Nina Veflen Olsen & 2 \\
\hline Michele Roccato & 2 \\
\hline Eugenia Scabini & 2 \\
\hline David Schiefer & 2 \\
\hline Bart Soenens & 2 \\
\hline Alessio Vieno & 2 \\
\hline
\end{tabular}

Table 4. Journal where more than one article considered in the review were published

\begin{tabular}{ll}
\hline Journal & Number of articles \\
International Journal of Intercultural Relations & 3 \\
\hline Personality and Individual Differences & 3 \\
\hline International Journal of Psychology & 2 \\
\hline European Journal of Social Psychology & 2 \\
\hline Journal of Cross-Cultural Psychology & 2 \\
\hline Journal of Moral Education & 2 \\
\hline Journal of Personality & 2 \\
\hline Political Psychology & 2 \\
\hline Sex Roles & 2 \\
\hline
\end{tabular}

Table 5. Number of articles published per year

\begin{tabular}{lc}
\hline Year & Number of articles \\
\hline 2007 & 4 \\
\hline 2008 & 3 \\
\hline 2009 & 5 \\
\hline 2010 & 6 \\
\hline 2011 & 6 \\
\hline 2012 & 9 \\
\hline 2013 & 12 \\
\hline 2014 & 13 \\
\hline
\end{tabular}

The second aim of this study was to carry out a methodological analysis of the PVQ, the instrument developed by Schwartz and his colleagues (2011) to assess the ten basic human values he theorised. We first determined which version of the instrument was administered to each of the samples detailed in the studies. In most cases $(\mathrm{N}=30)$, the original version of the instrument was used, meaning the one with 40 items (PVQ-40). In thirteen cases, however, the reduced version (PVQ-21) was administered. In some studies $(\mathrm{N}=9)$, an even more reduced version of the instrument, comprised only of selected items, was used to assess only a limited number of the basic human values or some of the higher-order dimensions theorised by Schwartz. In these cases, the number and the choice of which items to administer to the sample depended on the aims of each given study. In one case, the 57 item Portrait Values Questionnaire used by Schwartz et al. (2012) was used, thus assessing the 19 values identified in the revised version of the theory (Schwartz \& Butenko, 2014). Elsewhere some studies $(\mathrm{N}=5)$, the did not reveal the version of the instrument used.

Many of the studies taken into consideration in our review assessed all ten basic human values theorised by Schwartz $(\mathrm{N}=34)$, while the remaining 22 studies focused only on a few of them. One study chose instead to use the refined version of Schwartz's Values Theory (Schwartz et al., 2012) to consider all of the 19 values proposed therein (Schwartz \& Butenko, 2014). This information is not available for one of the studies (Riekki, Lindeman, \& Lipsanen, 2013) (see Table 2). The review concluded that 36 out of 58 studies considered some or all of the ten basic human values, while 14 studies focused on the higher-order dimensions (Self-transcendence, Self-enhancement, Openness to Change and Conservation), each of which includes a number of these basic values. Three studies considered both of these classifications, arriving at different results depending on the value type used. Alternatively, two studies examined cultural values: according to Schwartz (1994), overall cultural values can be derived by aggregating individual-level questionnaire-based data. Schwartz (2006) explicitly defined the cultural values measured by each PVQ item. Thus, it is possible to calculate the respondents' scores by averaging the items that assess the same cultural value. Finally, one study considered traditional values (conformity, tradition and benevolence) versus modern values (stimulation, hedonism and achievement), while a final study pitted individualistic values (power, achievement, hedonism, stimulation and self-direction) against collectivist ones (conformity, tradition and benevolence). It was impossible to get this information for one study, since it used the PVQ within a wider survey to provide the respondents with a personal value profile as feedback to reward them for their participation (Riekki, Lindeman, \& Lipsanen, 2013).

As explained above, respondents completing the PVQ are asked to compare themselves to each portrait, giving their answers on a 6-point scale from $1=$ 'not like me at all' to $6=$ 'very much like $m e$ '. Most of the studies analysed kept this original response scale, but some changed it. These changes sometimes arose from the aims of the research, while in other cases they were meant to make the task easier for the respondents. In some studies, for example, respondents were required to answer on a 4-, 5- or 7-point Likert scale $(\mathrm{N}=7)$. In one study, the 6-point Likert scale was maintained, but the numerical values assigned to responses varied from 0 ('not like me at all') to 5 ('very much like me') (see 
Table 2). The instrument was usually administered in the native language of the respondents, as the PVQ has been validated in many different countries. The translations into the different languages were carried out using a strict back-translation procedure with bilingual translators. If the native-language version was not available, an English version was used.

The Portrait Values Questionnaire was mainly used for single-culture studies: in 16 studies, the scale was administered to an Italian sample. Only 12 articles are cross-cultural studies. Of these, five used the data from one or more round of the European Social Survey (ESS), an academically-driven cross-national survey that has been conducted in Europe every two years since 2002. Only in four cases out of 58 was the PVQ administered to assess values in a longitudinal study.

Furthermore, the scale was administered in various ways: it was sent by email to the respondents or through social networks, it was set up as an online survey, or the respondents filled out a paper-andpencil version of the scale, doing so individually or in small groups. All the samples made up of students featured data collected in their classrooms or during assemblies. In only one study were participants interviewed face-to-face by trained interviewers at home or in their workplaces, while in another one participants were interviewed over the phone. Participation in the research was almost always voluntary, but sometimes a small monetary reward was provided as compensation for participating $(\mathrm{N}=7)$, while students were rewarded with extra credit $(\mathrm{N}=4)$.

In terms of software, most of the studies in our review made no mention of the statistical data analysis programmes they used. Of the studies did name a programme (five studies mentioned more than one statistical programme), eight used SPSS as a general statistical programme, while the others used computer programmes that could be classified as SEM (structural equation modelling). These programmes are specifically intended to look for causal relations among the data. The following were used: Mplus $(\mathrm{N}=8)$, LISREL $(\mathrm{N}=4)$, Amos $(\mathrm{N}=4)$ and EQS $(\mathrm{N}=3)$. The authors mentioned a total of eight different statistical programmes (Systat, Mplus, Amos, HLM, LISREL, EQS, SPSS and HUDAP). This information about the statistical programmes used is in line with the analyses carried out in the studies, as they are mainly correlations, linear structural models and analyses of variance.

The sample sizes in the articles analysed (see Table 2) varied from a minimum of 12 people (Kjærgaard, Venables, Leon \& Fink, 2013) to a maximum of 44,955 people (for this study, data were drawn from the first and the fourth round of the ESS, respectively, in 2002 and in 2008) (Robinson, 2013).

The third aim of this study was to explore the different ways the PVQ is used in the scholarly literature. Considering the available data, it was possible to classify four different purposes for administering the instrument. In one study, the PVQ was administered to examine of whether it is possible to arrive at a finer-grained set of values, made up of of 19 in all. We regarded this use as an attempt to clarify and improve upon Schwartz's theory of human values; in fact, Schwartz himself was the author of this article. In two cases, however, the PVQ was used to validate other instruments that assess human values, specifically related to work contexts. Additionally, one of the 58 studies analysed did not aim to assess human values; the only reason the PVQ was administered to the sample was to give the participants a personal value profile as compensation for participating. The most important and prevalent use of the instrument was to analyse the relationships between human values and other variables, such as beliefs, behaviours, attitudes, etc. We have tried to explore this last use of the instrument more deeply because it is so widespread in the scholarly literature on this topic. To do so, we grouped these variables as the authors express them, using their language verbatim (Table 6).

In some of these cases 'values' was considered an independent variable, while in others it was taken as

Table 6. Variables analysed in relation to values

\begin{tabular}{|c|c|}
\hline $\begin{array}{l}\text { Sociodemographic } \\
\text { variables }\end{array}$ & $\begin{array}{l}\text { Age } \\
\text { Gender } \\
\text { Income } \\
\text { Employment } \\
\text { Education } \\
\text { Religion } \\
\text { Migration generation } \\
\text { Origin } \\
\text { Socioeconomic status }\end{array}$ \\
\hline $\begin{array}{l}\text { Variables related } \\
\text { to family }\end{array}$ & $\begin{array}{l}\text { Parents' socialization values } \\
\text { Children's acceptance of parents' socialization } \\
\text { values } \\
\text { Siblings' relationship quality } \\
\text { Preference for more than two children } \\
\text { Expectations of autonomy from children } \\
\text { and higher autonomy } \\
\text { Expectations from self } \\
\text { Autonomy from the family } \\
\text { Family dynamics }\end{array}$ \\
\hline Cultural variables & $\begin{array}{l}\text { Cultural values (in individuals with a migrant } \\
\text { background) } \\
\text { Identity style } \\
\text { Cultural orientations } \\
\text { Work values } \\
\text { Host community acculturation orientations } \\
\text { Civic engagement } \\
\text { Teachers' values } \\
\text { Patriotism }\end{array}$ \\
\hline $\begin{array}{l}\text { Attitudes, } \\
\text { behaviours, } \\
\text { perceptions } \\
\text { and beliefs }\end{array}$ & $\begin{array}{l}\text { Disgust reaction to moral transgression } \\
\text { Individual differences in negative group-related } \\
\text { attitudes } \\
\text { Attitudes towards pork production systems } \\
\text { Organizational citizenship behaviour } \\
\text { In-role performance } \\
\text { Organizational and occupational commitment } \\
\text { Political orientations } \\
\text { Self-efficacy beliefs } \\
\text { Perspective perception } \\
\text { Compliance behaviour } \\
\text { Moral disengagement } \\
\text { Liberal attitude towards gender role } \\
\text { Violent behaviours } \\
\text { Moral reasoning } \\
\text { Task performance } \\
\text { Orientations towards human rights } \\
\text { Perception of immigrants } \\
\text { Attitudinal consequences to support or oppose } \\
\text { a ceasefire government decision } \\
\text { Prosocial behavior } \\
\text { Consumption }\end{array}$ \\
\hline Others & $\begin{array}{l}\text { Perceived changes in health and interactions } \\
\text { Hierarchical status } \\
\text { Traits } \\
\text { Life satisfaction } \\
\text { Posttraumatic stress symptoms } \\
\text { Type of school } \\
\text { Time }\end{array}$ \\
\hline
\end{tabular}


the dependent variable. Human values were also approached as correlated variables or as mediators between two other variables.

\section{Discussion}

This study was aimed at highlighting studies that have analysed the role of human values in different life situations, and that in doing so have used the Portrait Values Questionnaire (Schwartz et al., 2001) to assess these values, all in pursuit of a variety of research aims.

Findings show that there is no one journal that specifically deals with human values: this informs us of the cross-cutting nature not only of the overall concept of values, but also of the instrument itself, which was used in fields as diverse as military psychology (Kjærgaard, Venables, Leon, \& Fink, 2013) and food preferences (Olsen et al., 2010).

The authors who have carried out research into this topic come from different countries, although a considerable number of studies were conducted by Italian researchers. However, all of them (with only two exceptions) were written in English: this is fundamental for a study to be widely circulated throughout the scholarly community. Once again, Schwartz's model was confirmed by more than 200 studies in 60 countries, with researchers employing samples from different geographic regions, languages, religions, ages, sexes and occupations (Schwartz \& Bilsky, 1987, 1990; Schwartz, 1994; Sagiv \& Schwartz, 1995). However, most of the studies examine a single culture. Nonetheless, the key role played by the data collected through the European Social Survey for the few authors who did conduct cross-cultural studies on this topic is worth noting. In fact, the cross-cultural studies that included more than four countries and had large samples all were able to do so thanks to this data. As shown in Table 2, the samples of the different studies appear to be highly heterogeneous, as they vary greatly in size. The researchers' use of the instrument under such dissimilar conditions validates the universality of Schwartz's theory of human values.

A further consideration is that versions of the PVQ beyond the two validated ones (PVQ-40 or PVQ-21) were sometimes used. These departures might affect the metric properties of the instrument. Even the response scale was often modified.

In terms of the average age of the studies' samples, it is very worth noting that the PsycINFO search usingdid not only turn up young adults as was expected. Although the age range entered into the 'Age Group' search field was from 18 to 29 years old, a considerable number of studies dealt with adolescents, while many of them focused on a wider age range. Only nine studies focused exclusively on the age range that is more or less considered 'young adult' by the scholarly literature. Moreover, it is interesting to observe that, even though the keyword used in our search was 'Portrait Values Questionnaire', some of the studies that appeared as search results used the previous instrument developed by the same author (the SVS) $(\mathrm{N}=2)$, while others only touched upon his theory but not use the instrument ( $\mathrm{N}=1)$ (Busacca, Beebe, \& Toman, 2010; Venus, Stam \& van Knippenberg, 2013; Zhang, Ly, \& Grigoriou, 2008). These works were thus excluded from our review.

In conclusion, the results of our review are further proof of the transversality of this topic: in fact, we can note that human values were examined by researchers from a wide variety of fields and with various kinds of aims.

\section{References}

American Psychological Association (2015). What is PsycINFO? Retrieved from http://www.apa.org/support/databases/psycinfo/description.aspx\#answer

Arieli, S., Grant, A. M., \& Sagiv, L. (2014). Convincing yourself to care about others: An intervention for enhancing benevolence values. Journal of Personality, 82(1), 15-24.

Arnett, J. J. (2004). Emerging adulthood: The winding road from the late teens through the twenties. New York: Oxford University Press.

Avallone, F., Farnese, M. L., Pepe, S., \& Vecchione, M. (2010). The Work Values Questionnaire (WVQ): Revisiting Schwartz's Portrait Values Questionnaire (PVQ) for work contexts. Bollettino di Psicologia Applicata, 261-262, 59-65.

Barni D., Ranieri S., Scabini E., \& Rosnati, R. (2011). Value transmission in the family: Do adolescents accept the values their parents want to transmit? Journal of Moral Education, 40(1), 105-121

Barni, D., Alfieri, S., Marta, E., \& Rosnati, R. (2013). Overall and unique similarities between parents' values and adolescent or emerging adult children's values. Journal of Adolescence, 36(6), 1135-1141.

Barni, D., Roccato, M., Vieno, A., \& Alfieri, S. (2014). Birth order and conservatism: A multilevel test of Sulloway's «Born to rebel» thesis. Personality and Individual Differences, 66, 58-63.

Barni, D., Vieno, A., Rosnati, R., Roccato, M., \& Scabini, E. (2014). Multiple sources of adolescents' conservative values: A multilevel study. The European Journal of Developmental Psychology, 11(4), 433-446.

Bender, M., \& Chasiotis, A. (2011). Number of siblings in childhood explains cultural variance in autobiographical memory in Cameroon, People's Republic of China, and Germany. Journal of Cross-Cultural Psychology, 42(6), 998-1017.

Benish-Weisman, M., Levy, S. \& Knafo, A. (2013). Parents differentiate between their personal values and their socialization values: The role of adolescents' values. Journal of Research on Adolescence, 23(4), 614620.

Berzonsky, M. D., \& Papini, D. R. (2014). Identity Processing Styles and Value Orientations: The Mediational Role of Self-Regulation and Identity Commitment. Identity: An International Journal of Theory and Research, 14(2), 96-112. 
Boratav, H.B. (2009). Values and attitudes of young people in urban Turkey: A further test of Schwartz's theory of values and Kağitçibaşi's model of family change. In Bekman S., Aksu-Koç A. (Eds.), Perspectives on human development, family, and culture (pp. 263283). New York: Cambridge University Press.

Burr, A., Santo, J. B., \& Pushkar, D. (2014). Investigating the Portrait Values Questionnaire at two transitions in adulthood: Retirement and University. Quality and Quantity, 48(2), 1027-1044.

Busacca, L. A., Beebe, R. S., \& Toman, S. M. (2010). Life and work values of counselor trainees: A national survey. The Career Development Quarterly, 59(1), 2-18.

Caprara, G.V., \& Steca, P. (2007). Prosocial agency: The contribution of values and self-efficacy beliefs to prosocial behavior across ages. Journal of Social and Clinical Psychology, 26(7), 218-239.

Caprara, G.V., Francescato, D., Mebane, M., Sorace, R., $\&$ Vecchione, M. (2010). Personality foundations of ideological divide: A comparison of women members of Parliament and women voters in Italy. Political Psychology, 31(5), 739-762.

Caprara, G. V., Alessandri, G., \& Eisenberg, N. (2012). Prosociality: The contribution of traits, values, and self-efficacy beliefs. Journal of Personality and Social Psychology, 102(6), 1289-1303.

Cieciuch J., \& Schwartz S. H. (2012). The number of distinct basic values and their structure assessed by PVQ-40, Journal of Personality Assessment, 94(3), 321328.

Cohen, A., \& Liu, Y. (2011). Relationships between inrole performance and individual values, commitment, and organizational citizenship behavior among Israeli teachers. International Journal of Psychology, 46(4), 271-287

Cohrs, J. C., Maes, J., Moschner, B., \& Kielmann, S. (2007). Determinants of human rights attitudes and behavior: A comparison and integration of psychological perspectives. Political Psychology, 28(4), 441-469.

Davidov, E., Schmidt, P., \& Schwartz, S. H. (2008). Bringing values back in: The adequacy of the European Social Survey to measure values in 20 countries. Public Opinion Quarterly, 72(3), 420-445.

De Barcellos, M. D., Teixeira, C. M., \& Venturini, J. C. (2014). Personal values associated with political consumption: An exploratory study with university students in Brazil. International Journal of Consumer Studies, 38(2), 207-216.

Delkhamous, M. T., \& Ahmadi, M. (2013). Culturespecifics in Iranian values: A study in three samples of three generations. Journal of Iranian Psychologists, 34(9), 107-128.

Dirilen-Gumus, O., \& Buyuksahin-Sunal, A. (2012). Gender differences in Turkish undergraduate students' values. Sex Roles, 67(9-10), 559-570.

Döring, A. (2010). Assessing Children's Values: an Exploratory Study. Journal of Psychoeducational Assessment, 28(6), 1-14.

Duriez, B., Soenens, B., \& Vansteenkiste, M. (2007). In search of the antecedents of adolescent authoritarian- ism: The relative contribution of parental goal promotion and parenting style dimensions. European Journal of Personality, 21(4), 507-527

Duriez, B., Luyckx, K., Soenens, B., \& Berzonsky, M. (2012). A process-content approach to adolescent identity formation: Examining longitudinal associations between identity styles and goal pursuits. Journal of Personality, 80(1), 135-161.

Gerbino, M., Alessandri, G., \& Caprara, G. V. (2008). Valori, disimpegno morale e violenza nei giovani adulti/Values, moral disengagement and violence in young adults. Età Evolutiva, 90, 88-96.

Goodwin, R., Polek, E., \& Goodwin, K. (2013). Perceived changes in health and interactions with «the paracetamol force»: A multimethod study. Journal of Mixed Methods Research, 7(2), 152-172.

Grassi, R. (2007). I valori dei giovani trentini. In C. Buzzi (Eds.), Generazioni in movimento. Madri e figli nella seconda indagine Istituto Iard - Iprase sulla condizione giovanile in Trentino (pp. 117-136). Bologna: Il Mulino

Güngör, D., \& Bornstein, M. H. (2009). Gender, development, values, adaptation, and discrimination in acculturating adolescents: The case of Turk heritage youth born and living in Belgium. Sex Roles, 60(7-8), 537-548.

Güngör, D., Bornstein, M. H., \& Phalet, K. (2012). Religiosity, values, and acculturation: A study of Turkish, Turkish-Belgian, and Belgian adolescents. International Journal of Behavioral Development, 36(5), 367-373.

Hofmann IV, J. G. (2010). The multidimensional structure and function of human values. Dissertation Abstracts International Section A: Humanities and Social Sciences, 71(1-A), 83.

Hofmann-Towfigh, N. (2007). Do students' values change in different types of schools? Journal of Moral Education, 36(4), 453-473.

Holtschlag, C., Morales, C. E., Masuda, A. D., \& Maydeu-Olivares, A. (2013). Complementary person-culture values fit and hierarchical career status, Journal of Vocational Behavior, 82(2), 144-153.

Kjærgaard, A., Leon, G. R., Venables, N. C., \& Fink, B. A. (2013). Personality, personal values and growth in military special unit patrol teams operating in a polar environment. Military Psychology, 25(1), 13-22.

Kretschmer, T., \& Pike, A. (2010). Associations between adolescent siblings' relationship quality and similarity and differences in values. Journal of Family Psychology, 24(4), 411-418.

Kulik, L., \& Erantal, T. (2009). Contemporary family relationships and life values: A comparative analysis of men and women in Israel. Families in Society, 90(2), 231-238.

Luengo Kanacri, B. P., Pastorelli, C., Zuffianò, A., Eisenberg, N., Ceravolo, R., \& Caprara, G. V. (2014). Trajectories of prosocial behaviors conducive to civic outcomes during the transition to adulthood: The predictive role of family dynamics. Journal of Adolescence, 37(8), 1529-1539. 
Liu, Y.-C., Gijsen, J., \& Tsai, C.-Y. (2014). An empirical evaluation of ethnolinguistic vitality and language loss: The case of Southern Min in Taiwan. Folia Linguistica, 47(2), 425-448.

Livi, S., Leone, L., Falgares, G., \& Lombardo, F. (2014). Values, ideological attitudes and patriotism. Personality and Individual Differences, 64, 141-146.

Luengo Kanacri, B. P., Rosa, V., \& Di Giunta, L. (2012). The mediational role of values in linking personality traits to civic engagement in Italian youth. Journal of Prevention \& Intervention in the Community, 40(1), 8-21.

Maercker, A., Mohiyeddini, C., Müller M., Xie, W., Yang, Z.H., Wang, J., \& Müller, J. (2009). Traditional versus modern values, self-perceived interpersonal factors, and posttraumatic stress in Chinese and German crime victims. Psychology and Psychotherapy: Theory, Research and Practice, 82(2), 219-232.

Moher, D., Liberati, A., Tetzlaff, J., \& Altman, D. G., \& The PRISMA Group (2009). Preferred reporting items for systematic reviews and meta-analysis: The PRISMA statement. Plos, Medecine, 6(7), e1000097.

Montero, I., \& Leon, O.G (2007). A guide of naming research studies in Psychology. International Journal of Clinical and Health Psychology, 7(3), 847-862.

Nir, L., \& Knafo A. (2009). Reason within passion: Values as motivational anchors of Israeli opinion on the 2006 Lebanon War and ceasefire. Values, empathy, and fairness across social barriers. In Vilarroya, O., Altran, S., Navarro, A., Ochsner, K., Tobeña, A. (Eds.) (2009), Values, empathy, and fairness across social barriers. Annals of the New York Academy of sciences (pp. 46-157). New York: New York Academy of Sciences.

Olsen, N. V., Menichelli, E., Grunert, K. G., Sonne, A. M., Szabó, E., Bánáti, D., \& Næs, T. (2011). Choice probability for apple juice based on novel processing techniques: Investigating the choice relevance of mean-end-chains. Food Quality and Preference, 22(1), 48-59.

Ottaviani, C., Mancini, F., Petrocchi, N., Medea, B., \& Couyoumdjian, A. (2013). Autonomic correlates of physical and moral disgust. International Journal of Psychophysiology, 89(1), 57-62.

Özcan, H. U. (2012). Birey-Örgüt Değerleri Arasındaki Uyumun Örgütle Özdeşleşme ile İlişkisi./The effects of person-organization value fit on organizational identification. Türk Psikoloji Yazilari, 15(29), 25-39.

Paciello, M., Fida, R., Tramontano, C., Cole, E., \& Cerniglia, L. (2013). Moral dilemma in adolescence: The role of values, prosocial moral reasoning and moral disengagement in helping decision making. European Journal of Developmental Psychology, 10(2), 190-205.

Pallini, S., Bove, G., \& Laghi, F. (2011). Classification of professional values based on motivational content: An exploratory study on Italian adolescents. Measurement and Evaluation in Counseling and Development, 44(1), 16-31.

Riekki, T., Lindeman, M., \& Lipsanen, J. (2013). Conceptions about the mind-body problem and their relations to afterlife beliefs, paranormal beliefs, religiosity, and ontological confusions. Advances in Cognitive Psychology, 9(3), 112-120.

Robinson, O. C. (2013). Values and adult age: Findings from two cohorts of the European Social Survey. European Journal of Ageing, 10(1), 11-23.

Rokeach, M. (1973). The nature of human values. New York: Free Press.

Sagiv, L., \& Schwartz, S.H. (1995). Values Priorities and Readiness for Outgroup Social Contract. Journal of Personality and Social Psychology, 69(3), 437-448.

Saiz, J., Álvaro, J. L., \& Martínez, I. (2011). Relación entre rasgos de personalidad y valores personales en pacientes dependientes de la cocaína./Relation between personality traits and personal values in cocaine-dependent patients. Adicciones, 23(2), 125-132.

Sandy, C. J., Gosling, S. D., \& Koelkebeck, T. (2014). Psychometric Comparison of Automated Versus Rational Methods of Scale Abbreviation. Journal of Individual Differences, 35(4), 221-235.

Sapienza, I., Hichy, Z., Guarnera, M., \& Di Nuovo, S. (2010). Effects of basic human values on host community acculturation orientations. International Journal of Psychology, 45(4), 311-319.

Schermer, J. A., Feather, N. T., Zhu, G., \& Martin, N. G. (2008). Phenotypic, genetic, and environmental properties of the Portrait Values Questionnaire. Twin Research and Human Genetics, 11(5), 531-537.

Schiefer, D. (2013). Cultural values and group-related attitudes: A comparison of individuals with and without migration background across 24 countries. Journal of Cross-Cultural Psychology, 44(2), 245-262.

Schiefer, D., Möllering, A., Daniel, E., Benish-Weisman, M., \& Boehnke, K. (2010). Cultural values and outgroup negativity: A cross-cultural analysis of early and late adolescents. European Journal of Social Psychology, 40(4), 635-651.

Schouten, B. C. (2008). Compliance behavior and the role of ethnic background, source expertise, selfconstruals and values. International Journal of Intercultural Relations, 32(6), 515-523.

Schwartz, S. H. (1992). Universals in the content and structure of values: Theory and empirical tests in 20 countries. In M. Zanna (Eds.), Advances in experimental social psychology (pp. 1-65). San Diego: Academic Press.

Schwartz, S.H (1994). Are There Universal Aspects in the Structure and in the Content of Human Values? Journal of Social Issues, 50(4), 19-45.

Schwartz, S. H. (2003). A proposal for measuring value orientations across nations. Chapter 7 in the Questionnaire Development Report of the European Social Survey. Retrieved from the web site: http://www. europeansocialsurvey.org/

Schwartz, S. H. (2006). A theory of cultural value orientations: Explication and applications. Comparative Sociology, 5(2-3), 137-182.

Schwartz, S.H., \& Bilsky, W. (1987). Toward a universal psychological structure of human values. Journal of Personality and Social Psychology, 53(3), 550-562. 
Schwartz, S.H., \& Bilsky, W. (1990). Toward a theory of the universal content and structure of values: extensions and cross-cultural replications. Journal of Personality and Social Psychology, 58(5), 878-891.

Schwartz, S. H., Melech, G., Lehmann, A., Burgess, S., \& Harris, M. (2001). Extending the cross-cultural validity of the theory of basic human values with a different method of measurement. Journal of CrossCultural Psychology, 32(5), 519-542.

Schwartz, S. H., Cieciuch, J., Vecchione, M., Davidov, E., Fischer, R., Beierlein, C., ... Konty, M. (2012). Refining the theory of basic individual values. Journal of Personality and Social Psychology, 103(4), 663-688.

Schwartz, S. H., \& Butenko, T. (2014). Values and behavior: Validating the refined value theory in Russia. European Journal of Social Psychology, 44(7), 799-813.

Sevgili, F., \& Cesur, S. (2014). The Mediating Role of Materialism on the Relationship between Values and Consumption. Educational Sciences: Theory \& Practice, 14(6), 2083-2096.

Śliwak, J., Zarzycka, B. (2013). Is it possible to discriminate the value patterns of Wulff ss approaches to religion in a Polish sample? Psychologica Belgica, 53(2), 33-49.

Solano, A. C., \& Nader, M. (2006). La evaluación de los valores humanos con el Portrait Values Questionnaire de Schwartz [Human values assessment with Schwartz's Portrait Values Questionnaire]. Interdisciplinaria Revista de Psicología y Ciencias Afines, 23, 155-174.

Sørensen B. T., Barcellos, M.D., Olsen, N. V., Verbeke, W., Scholderer, J. (2012). Systems of attitudes towards production in the pork industry. A cross-national study. Appetite, 59(3), 885-897.

Steinmetz, H., Schmidt, P., Tina-Booh, A., Wieczorek, S., \& Schwartz S. H. (2009). Testing measurement invariance using multigroup CFA: Differences between educational groups in human values measurement. Quality \& Quantity: International Journal of Methodology, 43(4), 599-616.

Tamayo, A., \& Porto, J. B. (2009). Validação do Questionário de Perfis de Valores (QPV) no Brasil/Validi- ty of the Portrait Values Questionnaire (PVQ) in Brazil. Psicologia: Teoria e Pesquisa, 25(3), 369-376.

Tulviste, T., Konstabel, K., \& Tulviste, P. (2014). Stability and change in value consensus of ethnic Estonians and Russian-speaking minority. International Journal of Intercultural Relations, 39(1), 93-102.

Verkasalo, M., Lönnqvist, J.-E., Lipsanen, J. \& Helkama, K. (2009). European norms and equations for a two dimensional presentation of values as measured with Schwartz's 21-item Portrait Values Questionnaire. European Journal of Social Psychology, 39(5), 780-792. Vecchione, M., Casconi, T., \& Barbaranelli, C. (2015). Assessing the Circular Structure of the Portrait Values Questionnaire: A Confirmatory Factor Analysis Approach. European Journal of Psychological Assessment, 25(4), 231-238.

Vecchione, M., Caprara, G., Schoen, H., Castro, J. L. G., \& Schwartz, S. H. (2012). The role of personal values and basic traits in perceptions of the consequences of immigration: A three-nation study. British Journal of Psychology, 103(3), 2012, 359-377.

Venus, M., Stam, D., \& van Knippenberg, D. (2013). Leader emotion as a catalyst of effective leader communication of visions, value-laden messages, and goals. Organizational Behavior and Human Decision Processes, 122(1), 53-68.

Vollmer, C., \& Randler, C. (2012). Circadian preferences and personality values: Morning types prefer social values, evening types prefer individual values. Personality and Individual Differences, 52(6), 738-743.

Výrost, J., Fedáková, D., \& Kentoš, M. (2010). Confirmation bias effects in the welfare beliefs of the residents of European countries. Studia Psychologica, 52(4), 327-332.

Woehr, D. J., Arciniega, L. M., \& Poling, T. L. (2013). Exploring the effects of value diversity on team effectiveness. Journal of Business and Psychology, 28(1), 107-121.

Zhang, X., Ly, L., \& Grigoriou, N. (2008). The myth of China as a single market - The influence of personal value differences on buying decisions. International Journal of Market Research, 50(3), 377-40. 